\title{
Design of fast crystallization of nanosized zeolite omega crystals at higher temperatures
}

\author{
Fen Zhang a, Ling Zhang a, Zhichao Yang b, Shichao Han a, Qiuyan Zhu a, Liang Wang a, \\ Chenguang Liu ${ }^{b}$, Xiangju Meng a,*, Feng-Shou Xiao a,\# \\ a Key Laboratory of Applied Chemistry of Zhejiang Province, Department of Chemistry, Zhejiang University, Hangzhou 310028, Zhejiang, China \\ b State Key Laboratory of Heavy Oil Processing, Key Laboratory of Catalysis, China National Petroleum Corp. (CNPC), China University of Petroleum (East \\ China), Qingdao 266580, Shandong, China
}

\section{A R T I C L E I N F O}

\section{Article history:}

Received 9 November 2018

Accepted 8 December 2018

Published 5 July 2019

\section{Keywords:}

Zeolite omega

Fast crystallization

High temperature

Pt nanoparticles

Hydroisomerization

\begin{abstract}
A B S T R A C T
Fast crystallization of nanosized zeolite crystals is a very popular process used for practical zeolite catalyst applications. Herein, we report a designer crystallization process for nanosized zeolite omega crystals based on the relationship between the crystallization time and temperature in the Arrhenius equation. Compared to the conventional hydrothermal synthesis of zeolite omega $72 \mathrm{~h}$ at room temperature and $240 \mathrm{~h}$ at $100{ }^{\circ} \mathrm{C}, \mathrm{MAZ}-100$ ), the crystallization of zeolite omega presented in this work only requires a very short time interval $\left(5 \mathrm{~h}\right.$ at $180{ }^{\circ} \mathrm{C}$, MAZ-180). Physicochemical characterizations, including XRD, SEM, $\mathrm{N}_{2}$ sorption isotherms, and ${ }^{27} \mathrm{Al}$ MAS NMR show that the product of zeolite omega (MAZ-180) has good crystallinity and uniform nanocrystals. More importantly, after the loading of Pt nanoparticles (0.5 wt\%), the Pt/H-MAZ-180 catalyst exhibits higher isomer selectivity and lower cracking selectivity than those of the Pt/H-MAZ-100 catalyst in the hydroisomerization of $n$-dodecane. These results suggest the potential applications of these omega nanocrystals as supporting catalyst compounds in industrial processes.
\end{abstract}

(C) 2019, Dalian Institute of Chemical Physics, Chinese Academy of Sciences. Published by Elsevier B.V. All rights reserved.

\section{Introduction}

Zeolites are considered as promising adsorbents, ion-exchangers, and catalysts, and have been extensively applied in industrial processes [1-15]. Zeolite omega, an analogue to the natural mineral mazzite (MAZ), consists of gmelinite cages that are linked in columns parallel to the $c$-axis to form main pores with 12-membered rings [16]. Recently, increased attention has been paid on zeolite omega owing to its application in the alkylation of aromatics [17,18], hydrocracking [19], oil cracking [20], and in the isomerization of paraffin and aro- matics [19,21,22]. Coq et al. [19] reported that omega zeolite exhibits high selectivity for hydrocracking, while smaller omega particles permit the development of a nearly pure hydroisomerization catalyst. In turn, Perrotta et al. [20] showed that omega zeolites have increased $\alpha$ values in the cracking of $n$-hexane. Solinas et al. [22] reported that omega zeolite is highly active and selective in the isomerization of 1-methylnaphthalene. To-this-date, there are many reported examples of successful syntheses of zeolite omega. However, zeolite is associated with a relatively long crystallization time, and presents a major challenge for industrial applications ow-

\footnotetext{
*Corresponding author. Tel/Fax: +86-571-8273698; E-mail: mengxj@zju.edu.cn

\# Corresponding author. Tel/Fax: +86-571-8273698; E-mail: fsxiao@zju.edu.cn

This work was supported by the National Natural Science Foundation of China (91545111, 91634201, 21720102001), National Key Research and Development Program of China (2017YFB0702803), and Shell Foundation.

DOI: S1872-2067(19)63280-8 | http://www.sciencedirect.com/science/journal/18722067 | Chin. J. Catal., Vol. 40, No. 7, July 2019
} 
ing to its costly synthesis. Coossens et al. [23] reported a zeolite omega synthesis following a 3-day aging process at room temperature, and a 10 -d crystallization process at $100{ }^{\circ} \mathrm{C}$, in the presence of an organic template. Yang et al. [24] demonstrated zeolite omega synthesis in a $\mathrm{Na}_{2} \mathrm{O}-\mathrm{SiO}_{2}-\mathrm{Al}_{2} \mathrm{O}_{3}-\mathrm{H}_{2} \mathrm{O}$-glycerol system at $125^{\circ} \mathrm{C}$ for $45 \mathrm{~d}$ with extra silica as the silica source. Davis et al. [25] fabricated zeolite omega using dioxane as an organic template at $140{ }^{\circ} \mathrm{C}$ for $7 \mathrm{~d}$, and Fajula et al. [26] obtained zeolite omega in a $\mathrm{Na}_{2} \mathrm{O}-\mathrm{SiO}_{2}-\mathrm{Al}_{2} \mathrm{O}_{3}-\mathrm{TMA}_{2} \mathrm{O}-\mathrm{H}_{2} \mathrm{O}$ system at 100 ${ }^{\circ} \mathrm{C}$ for $15 \mathrm{~d}$. Additionally, Xu et al. [27] prepared zeolite omega using piperazine as an organic template at $150{ }^{\circ} \mathrm{C}$ in a 4 -d period, and Cui et al. [28] synthesized zeolite omega from layered natural magadiite at $120^{\circ} \mathrm{C}$ in a 10 -day period.

Conversely, it is well known from the Arrhenius equation that the crystallization time of zeolites could be significantly reduced at increased crystallization temperatures [29,30].

In this study, we systematically investigated the crystallization of zeolite omega at relatively low temperatures, and obtained the relationship between the crystallization time and crystallization temperature according to the Arrhenius equation. Subsequently, based on this relationship, we designed the fast crystallization of zeolite omega at higher temperatures. As expected, it was realized at $180{ }^{\circ} \mathrm{C}$ over a 5 -h period. The zeolite omega product formed had good crystallinity and uniform nanocrystals. Most importantly, this zeolite supported Pt catalyst (0.5 wt\% Pt/H-MAZ-180) and exhibited high selectivity for the isomers in the hydroisomerization of $n$-dodecane.

\section{Experimental}

\subsection{Materials}

Sodium aluminate $\left(\mathrm{NaAlO}_{2}, 36.6 \% \mathrm{Na}_{2} \mathrm{O}\right.$ and $43.3 \% \mathrm{Al}_{2} \mathrm{O}_{3}$, Sinopharm Chemical Reagent Co., Ltd.), sodium hydroxide (NaOH, AR, 96\%, Sinopharm Chemical Reagent Co., Ltd.), silica sol (LUDOX HS-40, 40\% $\mathrm{SiO}_{2}$ in $\mathrm{H}_{2} \mathrm{O}$, Sigma-Aldrich), tetramethylammonium hydroxide (TMAOH, 25\% in water, Aladdin), and ammonium nitrate $\left(\mathrm{NH}_{4} \mathrm{NO}_{3}, \mathrm{AR}, 99 \%\right.$, Beijing Chemical Reagent Co., Ltd.), were employed without further purification.

\subsection{Synthesis of zeolite omega}

In a typical run, $0.944 \mathrm{~g}$ of sodium aluminate was dissolved in $6.4 \mathrm{~g}$ of distilled water during stirring, followed by the addition of $0.532 \mathrm{~g}$ of sodium hydroxide. After stirring for $30 \mathrm{~min}$, $6.0 \mathrm{~g}$ of silica sol and $0.64 \mathrm{~g}$ of tetramethylammonium hydroxide were added gradually. The reaction mixture was stirred for $2 \mathrm{~h}$, and formed a gel with a molar ratio of $2.4 \mathrm{Na}_{2} \mathrm{O} / 10$ $\mathrm{SiO}_{2} / \mathrm{Al}_{2} \mathrm{O}_{3} / 0.24 \mathrm{TMA}_{2} \mathrm{O} / 1100 \mathrm{H}_{2} \mathrm{O}$, followed by the crystallization of the compound in an autoclave at temperatures in the range of 100 to $180{ }^{\circ} \mathrm{C}$. After filtration, washing, drying, and calcination remove the organic template, the zeolite omega product was collected. The $\mathrm{H}$-form of the sample was obtained following the ion-exchange with a solution of $1 \mathrm{~mol} / \mathrm{L}$ $\mathrm{NH}_{4} \mathrm{HNO}_{3}$ at room temperature for $2 \mathrm{~h}$, followed by its calcination at $500{ }^{\circ} \mathrm{C}$ for $4 \mathrm{~h}$. The process was repeated three times, and the $\mathrm{H}$-form of the product was finally obtained, which was designated as H-MAZ- $x$ ( $x$ stands for the crystallization temperature).

To quantify the crystallinity of the samples, the zeolite omega synthesized at $180{ }^{\circ} \mathrm{C}$ for $5 \mathrm{~h}$ was referred to as a $100 \%$ crystallinity sample.

\subsection{Characterization}

X-ray diffraction (XRD) patterns were measured with a Rigaku Ultimate VI X-ray diffractometer ( $40 \mathrm{kV}, 40 \mathrm{~mA}$ ) using $\mathrm{Cu} K \alpha_{1}$ radiation $(\lambda=1.5406 \AA$ ) $)$. Solid-state NMR spectra were measured with a Varian Infinity Plus 400 spectrometer. Scanning electron microscopy (SEM) images were acquired with a Hitachi SU-1510 electron microscope. Transmission electron micrograph (TEM) experiments were performed with a Hitachi HT-7700 transmission electron microscope. Additionally, $\mathrm{N}_{2}$ sorption experiments at the temperature of liquid nitrogen were measured on a Micromeritics TriStar II apparatus. Thermogravimetry-differential thermal analysis (TG-DTA) curves were acquired on a Perkin-Elmer TGA 7 unit at a heating rate of $10{ }^{\circ} \mathrm{C} / \mathrm{min}$ in air. The sample composition was analyzed by Perkin-Elmer inductively coupled plasma (ICP). The acidity of the catalysts was measured according to the temperature-programmed-desorption of ammonia ( $\mathrm{NH}_{3}$-TPD). The catalyst was prepared at $550{ }^{\circ} \mathrm{C}$ in a He flow for $1 \mathrm{~h}$, followed by the adsorption of $\mathrm{NH}_{3}$ at $100{ }^{\circ} \mathrm{C}$ for $1 \mathrm{~h}$. After saturation, the catalyst was purged by a He flow for $3 \mathrm{~h}$ to remove the physically adsorbed ammonia on the sample. Subsequently, desorption of $\mathrm{NH}_{3}$ was carried out from 100 to $600{ }^{\circ} \mathrm{C}$ with a heating rate of $2.5^{\circ} \mathrm{C} / \mathrm{min}$. The amount of $\mathrm{NH}_{3}$ desorbed from the sample was detected using a thermal conductivity detector.

\subsection{Catalytic tests}

H-MAZ-100 and H-MAZ-180 supported Pt catalysts which were prepared using the wet impregnation method using an appropriate amount of $\mathrm{Pt}\left(\mathrm{NH}_{3}\right)_{4} \mathrm{Cl}_{2}$. The samples were crushed to mesh sizes in the range of $20-40$ by a hand-operated press after they were dried at $100{ }^{\circ} \mathrm{C}$ overnight, and after their calcination at $450{ }^{\circ} \mathrm{C}$ for $3 \mathrm{~h}$. These were named as Pt/H-MAZ-100 and Pt/H-MAZ-180, respectively.

Hydroisomerization of $n-C_{12}$ was carried out in a fixed-bed reactor. First, catalysts were reduced in flowing hydrogen at $400{ }^{\circ} \mathrm{C}$ for $2 \mathrm{~h}$. Subsequently, $n-\mathrm{C}_{12}$ was pumped into the reactor [31]. The reaction conditions were as follows: the $\mathrm{H}_{2} / n$-dodecane $(V / V)$ ratio was equal to 400 , the pressure was 1.0 MPa, the weight hourly space velocity (WHSV) was set to $1.5 \mathrm{~h}^{-1}$, and the temperature was in the range of 300 to $380{ }^{\circ} \mathrm{C}$. The products were analyzed online using gas chromatography.

\section{Results and discussion}

Figs. S1 and S2 show XRD patterns and SEM images of fully crystallized omega crystals from 100 to $150{ }^{\circ} \mathrm{C}$ in the aluminosilicate gels in the presence of organic $\mathrm{TMAOH}$, which are well consistent with those of zeolite omega reported previously $[32,33]$. Fig. 1 shows the crystallization curves of the zeolite 


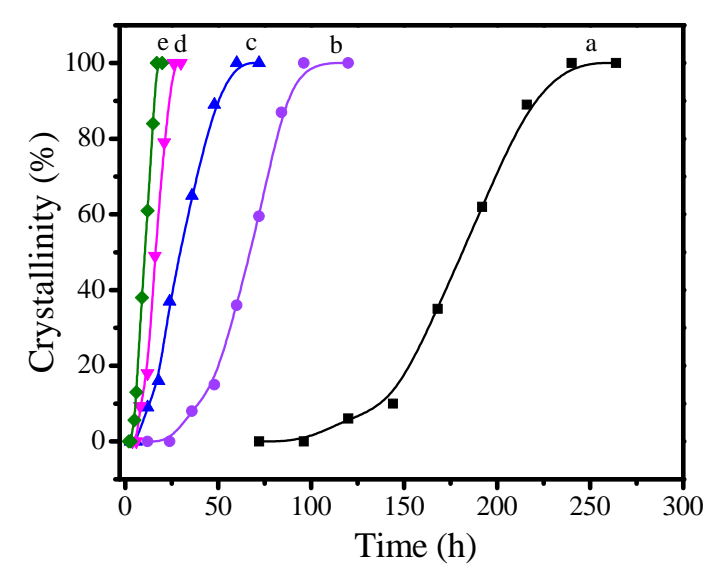

Fig. 1. Dependencies of omega zeolite crystallinity on crystallization time using TMAOH as the organic template at $100{ }^{\circ} \mathrm{C}(\mathrm{a}), 110{ }^{\circ} \mathrm{C}(\mathrm{b})$, $120^{\circ} \mathrm{C}(\mathrm{c}), 130^{\circ} \mathrm{C}(\mathrm{d})$, and $150^{\circ} \mathrm{C}(\mathrm{e})$.

omega in the temperature range from 100 to $150{ }^{\circ} \mathrm{C}$. Interestingly, the crystallization time was dependent on the crystallization temperature in the synthesis of zeolite omega. For example, the full crystallization of zeolite omega at $100{ }^{\circ} \mathrm{C}$ required $240 \mathrm{~h}$, while the full crystallization at $150^{\circ} \mathrm{C}$ required $17 \mathrm{~h}$.

Because the zeolite crystallization is a kinetic process, the growth of omega crystals could be expressed by the Arrhenius equation:

$$
\ln R_{1}=\text { constant }+\left(-E_{\mathrm{a}} / \mathrm{R} T\right)
$$

where $R_{1}$ denotes the crystallization rate, $E_{\mathrm{a}}$ is the activation energy of crystallization, and $T$ is the crystallization temperature. Because the reciprocal of the crystallization time linearly increases with the crystallization rate, Eq. (1) is simplified into Eq. (2) as follows:

$$
\ln (1 / t)=\mathrm{C}-E_{\mathrm{a}} / \mathrm{R} T
$$

where the $t$ is the crystallization time. If the values of $\ln (1 / t)$ are plotted as a function of $1 / T$ in the temperature range from 100 to $150{ }^{\circ} \mathrm{C}$, a linear relationship is obtained, as shown in Fig. 2. From the slope of this relationship, the activation energy for

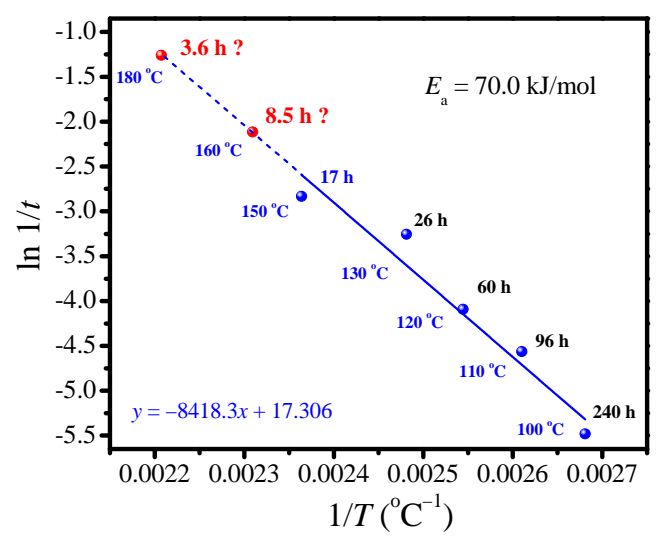

Fig. 2. Arrhenius plot for the synthesis of omega zeolite using TMAOH as the organic template. the omega crystallization can be estimated to equal to 70.0 $\mathrm{kJ} / \mathrm{mol}$. Therefore, we can predict any crystallization time for any temperature in the case of the synthesis of zeolite omega based on Eq. (2). Interestingly, if the crystallization temperature is selected to be $160{ }^{\circ} \mathrm{C}$, the crystallization time would be reduced to $8.5 \mathrm{~h}$. When the crystallization temperature is increased to $180{ }^{\circ} \mathrm{C}$, the crystallization time should be shortened to $3.6 \mathrm{~h}$. Even though we can theoretically predict the shortening of the crystallization time for zeolite omega using Eq. (2), this deviates for experimental syntheses of zeolite omega at temperatures higher than $150^{\circ} \mathrm{C}$. This may be related to a relatively difficult crystallization process at such high temperatures.

Table S1 presents the outcomes of a systematic investigation on the crystallization of zeolite omega at $180{ }^{\circ} \mathrm{C}$ from aluminosilicate gels in the presence of organic TMAOH. Interestingly, when the value of ratio of $\mathrm{Na}_{2} \mathrm{O} / \mathrm{SiO}_{2}$ in the gels is adjusted from 0.205 to 0.437 , products with amorphous phases are obtained, including a mixture of an amorphous phase with the omega (MAZ) structure, pure MAZ, a mixture of MAZ with the analcime (ANA) structure, and a pure ANA structure (Fig. S3). The $\mathrm{Na}_{2} \mathrm{O} / \mathrm{SiO}_{2}$ ratio for the crystallization of a pure MAZ structure was optimized and ranged from 0.305 to 0.338 . In addition, the $\mathrm{TMAOH} / \mathrm{SiO}_{2}$ ratio also influences the crystallization of zeolite omega. The $\mathrm{TMAOH} / \mathrm{SiO}_{2}$ ratio is below 0.038 , and the product is normally a mixture of an amorphous phase with MAZ. When this ratio reaches 0.046, a pure phase of the MAZ structure is elicited (Fig. S4). Furthermore, it is found that the $\mathrm{SiO}_{2} / \mathrm{Al}_{2} \mathrm{O}_{3}$ ratio is associated with the crystallization of zeolite omega. When the $\mathrm{SiO}_{2} / \mathrm{Al}_{2} \mathrm{O}_{3}$ ratio is lower than 10 , a mixture of MAZ with ANA is always elicited. When this ratio is distributed in the range of 10-20, it usually forms a pure phase in reference to the MAZ structure (Figs. S5 and S6). After the systematic synthesis, an appropriate form of aluminosilicate gel is obtained for the crystallization of zeolite omega at $180{ }^{\circ} \mathrm{C}$ with a molar ratio of $0.305 \mathrm{Na}_{2} \mathrm{O} / \mathrm{SiO}_{2} / 0.046 \mathrm{TMAOH} / 0.1 \mathrm{Al}_{2} \mathrm{O}_{3}$ $/ 110 \mathrm{H}_{2} \mathrm{O}$.

Fig. 3 shows the crystallization curves of omega zeolites

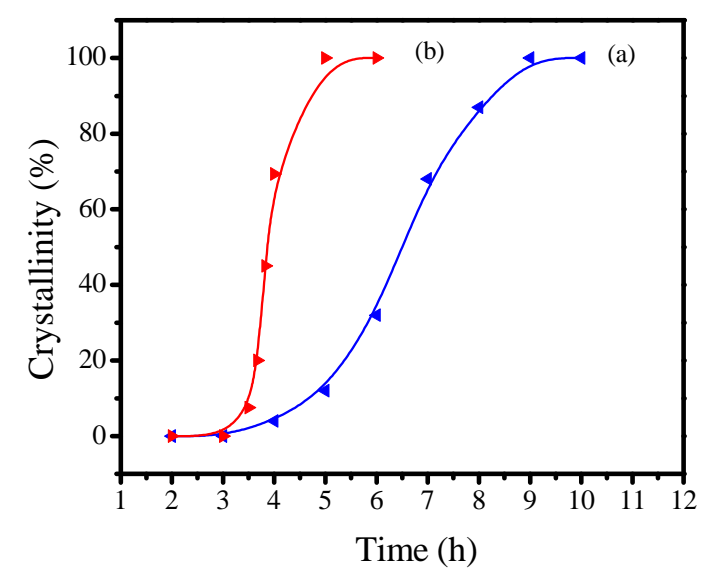

Fig. 3. Variations of zeolite omega crystallinity as a function of crystallization time using TMAOH as the organic template at $160{ }^{\circ} \mathrm{C}$ (a) and $180^{\circ} \mathrm{C}(\mathrm{b})$. 
from aluminosilicate gels with the optimized molar ratios at 160 and $180^{\circ} \mathrm{C}$. It is worth noting that the crystallization times at 160 and $180^{\circ} \mathrm{C}$ is ca. 9 and $5 \mathrm{~h}$, respectively, which are consistent with those elicited based on theoretical data shown in Fig. 2.

Fig. 4 displays the XRD pattern, SEM image, TEM image, nitrogen sorption isotherms, ${ }^{27} \mathrm{Al}$ NMR spectra, and the TG-DTA curve of the zeolite omega synthesized at $180^{\circ} \mathrm{C}$ (MAZ-180) for $5 \mathrm{~h}$. The XRD pattern of the as-synthesized MAZ-180 contains a series of characteristic peaks (Fig. 4(A)) associated with those reported previously [32,33], thus confirming the MAZ structure. After calcination, these peaks remain, thus indicating their good thermal stability (Fig. 4(A)). Fig. 4(B) shows a SEM image of the as-synthesized MAZ-180 with the assembled nanorods. These nanorods are uniform with widths of ca. $200 \mathrm{~nm}$ and lengths in the range of ca. $2-3 \mu \mathrm{m}$.

By contrast, conventional synthesis of zeolite omega at 100 ${ }^{\circ} \mathrm{C}$ (MAZ-100) yields larger crystals (widths of ca. $400 \mathrm{~nm}$ and lengths of ca. 5-6 $\mu \mathrm{m}$, Fig. S2). This phenomenon may be associated with the fact that higher temperatures have faster nucleation rates in the synthesis of zeolite omega. Notably, after ultrasonic treatment for $1 \mathrm{~h}$, the sample morphology is still retained (Fig. S7), thus suggesting that the assembled nanorods are stable.

Fig. 4(C) shows a TEM image of the as-synthesized MAZ-180, exhibiting clear micropores in the zeolite. Obviously, the corresponding SAED pattern of the MAZ-180 shows the electron pattern associated with the single crystal of the MAZ nanorods (insert in Fig. 4(C)). Fig. 4(C) shows the solid-state ${ }^{27} \mathrm{Al} \mathrm{NMR} \mathrm{spectrum} \mathrm{of} \mathrm{the} \mathrm{as-synthesized} \mathrm{and} \mathrm{calcined}$ MAZ-180 samples comprising two obvious signals at $\sim 60$ and $\sim 55 \mathrm{ppm}$, which can be assigned to the two T-sites in the MAZ framework [34]. In addition, we cannot observe a signal at 0 ppm associated with the extra framework of the Al species in the zeolite framework [35]. Figs. 4(E) and S8 show the $\mathrm{N}_{2}$ sorption isotherms of calcined MAZ-180 and calcined MAZ-100 indicating steep increases in the adsorbed volumes at a relative pressure less than 0.01 , which is owing to the filling of micropores. In addition, the hysteresis loop appeared to be at the relative pressure range of $0.5-0.95$. This is indicative of mesoporosity [36] that may be attributed to the spaces among the nanorods. The BET surface area and micropore volume of MAZ-180 are $187 \mathrm{~m}^{2} / \mathrm{g}$ and $0.05 \mathrm{~cm}^{3} / \mathrm{g}$. These values are similar to those of zeolite omega in the literature [28], as listed in Table S2. Fig. 4(F) displays the TG-DTA curves of the as-synthesized MAZ-180 in the temperature range from 25 to
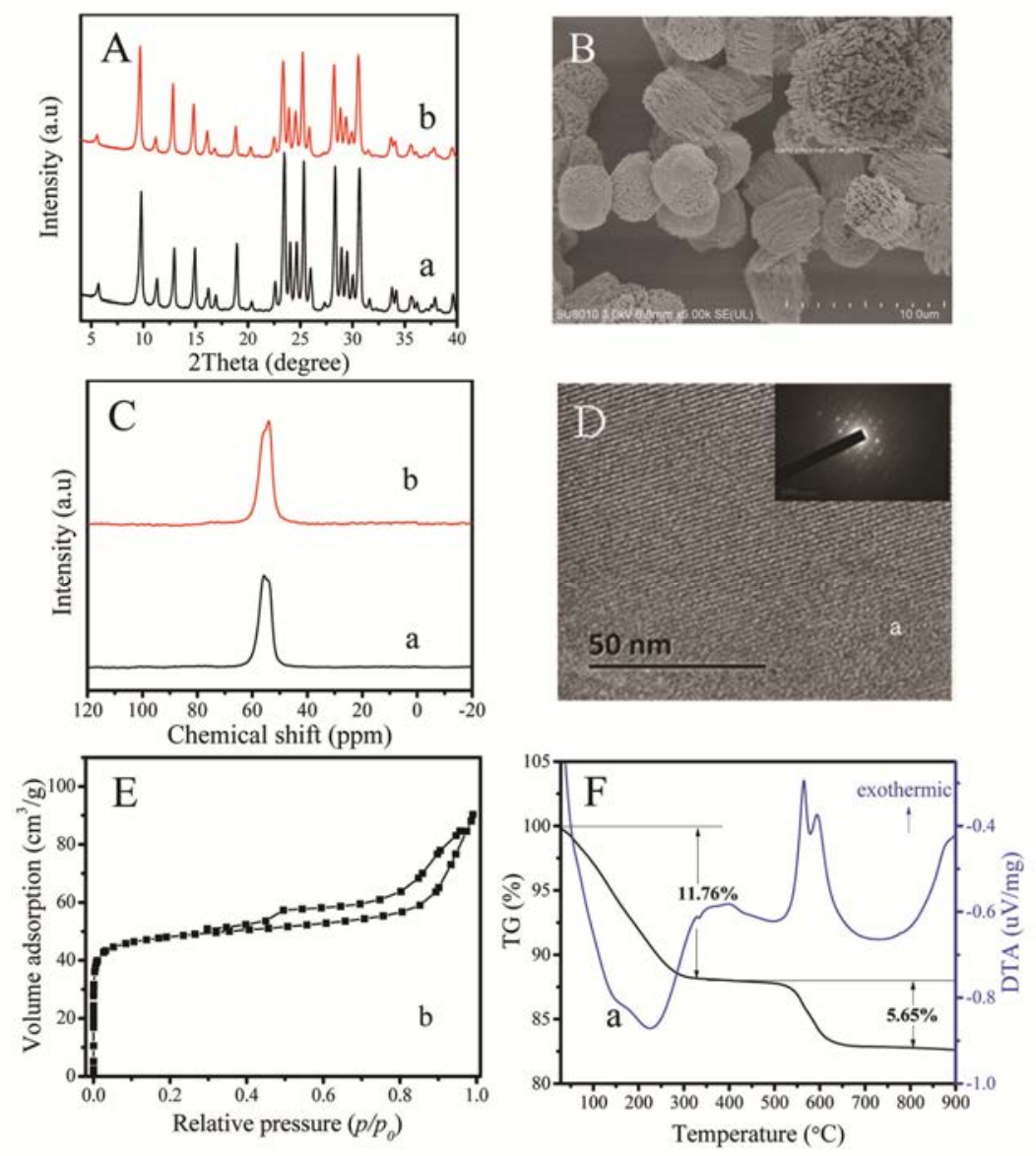

Fig. 4. XRD patterns (A), SEM image (B), ${ }^{27} \mathrm{Al}$ MAS NMR spectra (C), TEM image (D), $\mathrm{N}_{2}$ sorption isotherms (E), and TG and DTA curves (F) of as-synthesized (a) and calcined (b) MAZ-180 samples. The insert in B shows a high-resolution SEM image, while the insert in D shows the SAED pattern of the sample. 
$900{ }^{\circ} \mathrm{C}$. The weight loss associated with the adsorbed water appears to be below $250^{\circ} \mathrm{C}$, and the weight loss assigned to the combustion of organic templates shows that the temperature ranged from 300 to $650{ }^{\circ} \mathrm{C}$. After $700^{\circ} \mathrm{C}$, no obvious weight loss was observed. The DTA curve exhibits an endothermic peak within the temperature range of $100-250{ }^{\circ} \mathrm{C}$, while the main exothermic peaks occur at $400-600{ }^{\circ} \mathrm{C}$. These results suggest that the weight loss in the temperature ranges of 100-250 and 400-600 ${ }^{\circ} \mathrm{C}$ correspond to adsorbed water and to the organic template, respectively, and are accompanied by weight losses which are approximately equal to $11.76 \%$ and $5.65 \%$, respectively. Furthermore, the Si/Al ratio measured by the ICP technique is equal to 2.5 for MAZ-180. A brief summary of these characterizations confirms that MAZ-180 has a good crystallinity and contains uniform nanocrystals. The very short crystallization time could be important for the low-cost production of zeolite omega in industrial processes.

The acidity values of the H-MAZ-100 and H-MAZ-180 were measured with the $\mathrm{NH}_{3}$-TPD technique. The results showed that both samples had similar acidity values and strengths-a finding attributed to their similar $\mathrm{Si} / \mathrm{Al}$ ratios in the zeolite framework.

Given that long-chain paraffin hydroisomerization is one of the industrially important reactions, it has received increased attention owing to the requirement of fuel upgrading [37-42]. Normally, one-dimensional zeolites with 10-membered and 12-membered pore openings (e.g., SAPO-11, ZSM-48, and ZSM-22) are employed in the preparation of the hydroisomerization catalyst [43-49]. The fast crystallization of zeolite omega with one-dimensional, 12-membered pore openings in this work may offer a new opportunity for the preparation of highly efficient hydroisomerization catalysts. After loading similar $\mathrm{Pt}$ nanoparticles (0.5 wt\%), the Pt/H-MAZ-100 and Pt/H-MAZ-180 catalysts have similar Pt size distributions (Fig. S9) but they exhibit a significant difference in their catalytic performances in the hydroisomerization of $n$-dodecane. At any temperature, Pt/H-MAZ-180 always has a higher isomeric selectivity and a lower cracking selectivity than Pt/H-MAZ-100 catalysts, which may be related to their differences in nanocrystal sizes. Smaller and shorter one-dimensional zeolite crystals are favorable for the formation of isomers in the $n$-dodecane hydroisomerization [50-52].

\section{Conclusions}

In summary, we have designed a fast crystallization process for nanosized zeolite omega crystals based on the relationship between crystallization time and temperature in accordance with the Arrhenius equation. This design led to a crystallization time of $5 \mathrm{~h}$ at $180{ }^{\circ} \mathrm{C}$ (MAZ-180) which was much shorter than those reported previously. More importantly, the product of zeolite omega had good crystallinity and uniform nanocrystals.
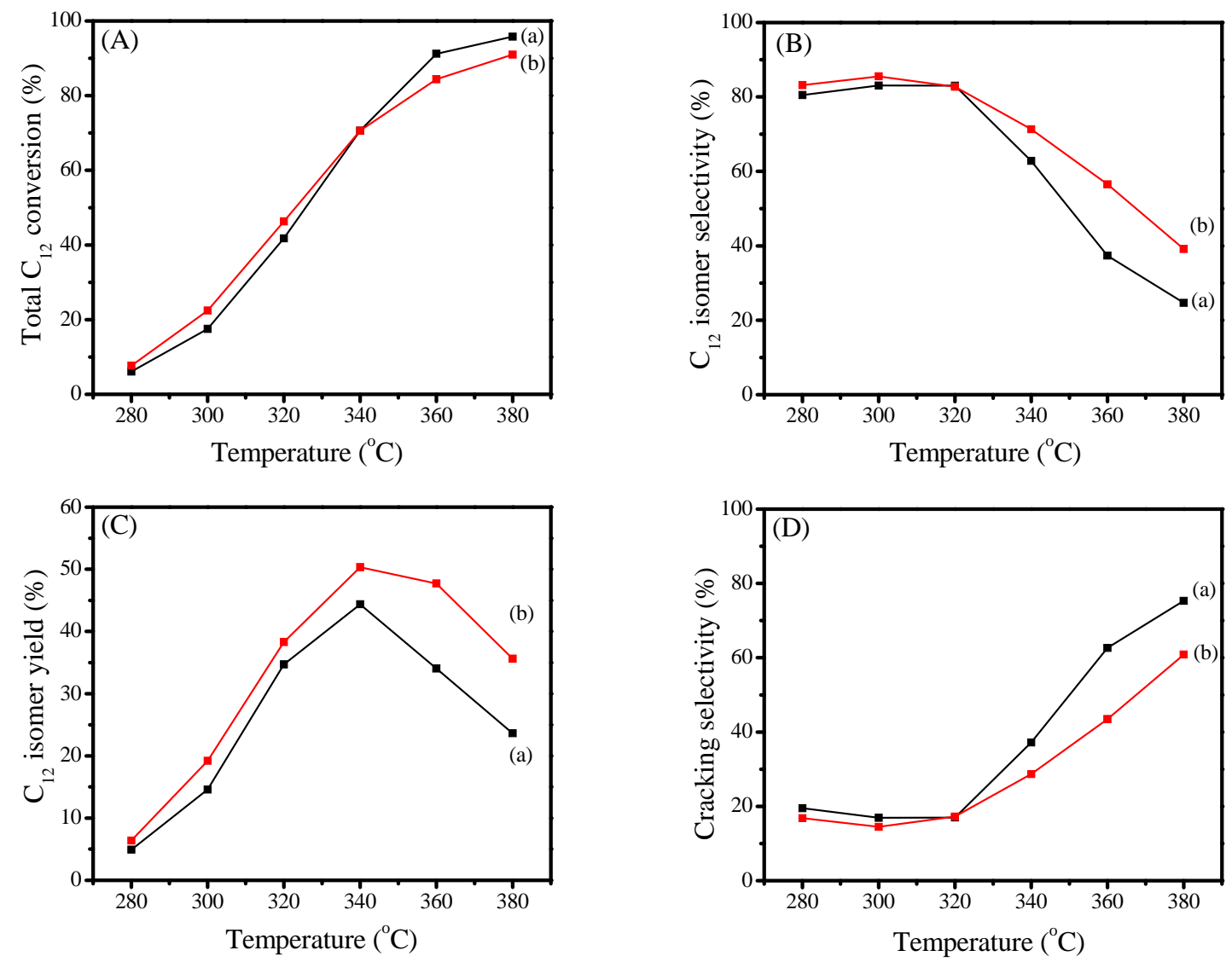

Fig. 5. Dependencies of conversion of $n$-dodecane (A), $C_{12}$ isomer selectivity (B), $C_{12}$ isomer yield (C), and cracking product selectivity (D) on reaction temperature for Pt/H-MAZ-100 (a) and Pt/H-MAZ-180 (b). 


\section{Graphical Abstract}

Chin. J. Catal., 2019, 40: 1093-1099 doi: S1872-2067(19)63280-8

\section{Design of fast crystallization of nanosized zeolite omega crys-} tals at higher temperatures

Fen Zhang, Ling Zhang, Zhichao Yang, Shichao Han, Qiuyan Zhu, Liang Wang, Chenguang Liu, Xiangju Meng *, Feng-Shou Xiao * Zhejiang University; China University of Petroleum (East China)

Design of fast crystallization of nanosized zeolite omega crystals based on the relationship between crystallization time and temperature according to the Arrhenius equation.

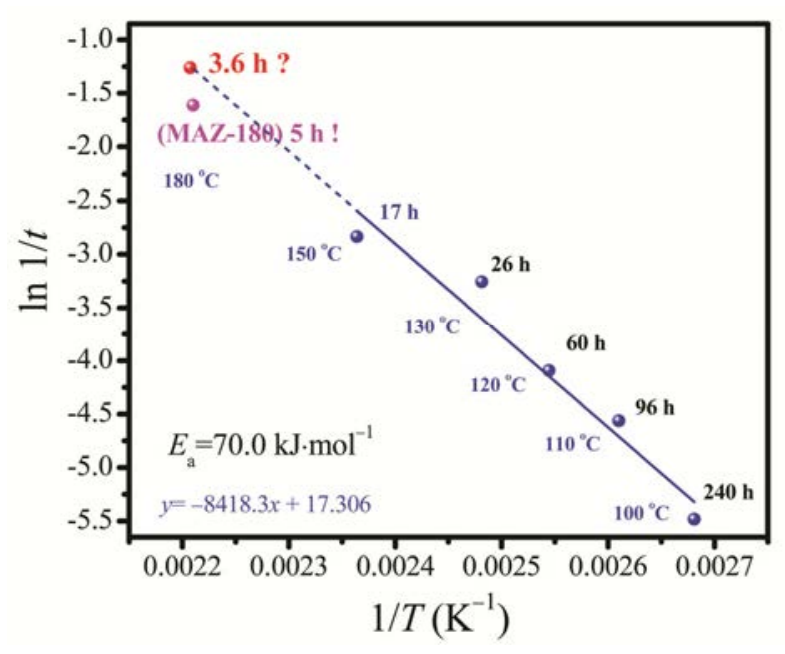

Microporous Mesoporous Mater., 2003, 63, 33-42.

[17] E. Flanigen, E. R. Kellberg, US Patent 4241 036, 1980.

[18] W. A. Erhart, C. E. Rohrer, US Patent 3578 728, 1971.

[19] B. Coq, F. Figueras, V. Rajaofanova, J. Catal., 1988, 114, 321-331.

[20] A. J. Perrotta, C. Kibby, B. R. Mitchell, E. R. Tucci, J. Catal., 1978, 55, 240-249.

[21] F. Raatz, C. Travers, C. Marcilly, T. Descourieres, F. Fajula, F. Figueras, US Patent 5157 198, 1991.

[22] V. Solinas, R. Monaci, B. Marongiu, L. Forni, Appl. Catal., 1983, 5, 171-177.

[23] A. M. Coossens, E. J. P. Fejien, G. Verhoeven, B. H. Wouters, P. J. Grobet, P. A. Jacobs, J. A. Martens, Microporous Mesoporous Mater., 2000, 35, 555-572.

[24] S. Yang, A. G. Vlessidis, N. P. Evmiridis, Microporous Mesoporous Mater., 1997, 9, 273-286.

[25] S. I. Zones, M. L. Occelli, H. Kessler, Marcel Dekker Inc., 1997, 93-94.

[26] F. Fajula, M. Verapacheco, F. Figueras, Zeolites, 1987, 7, 203-208.

[27] H. Xu, P. Dong, J. G. Wang, F. Deng, J. X. Dong, J. Porous Mater., 2007, 14, 97-101.

[28] M. Cui, Y. Wang, X. Y. Liu, J. Zhu, J. B. Sun, N. Lv, C. G. Meng, J. Chem. Technol. Biotechnol., 2014, 89, 419-424.

[29] J. H Guo, W. F. Yan, W. Shi, R. R. Xu. Chem. J. Chin. Univ., 2018, 39, 841-848.

[30] C. Q. Bian, C. S. Zhang, S. X. Pan, F Chen, W. P. Zhang, X. J. Meng, S. Maurer, D. Dai, A. N. Parvulescu, U. Muller, F.-S Xiao, J. Mater. Chem. A, 2017, 5, 2613-2618.

[31] Z. C. Yang, Y. Q. Liu, D. D. Liu, X. T. Meng, C. G. Liu. Appl. Catal. A, 2017, 543, 274-282.

[32] S. Inagaki, T. Yokoi, Y. Kubota, T. Tatsumi, Chem. Commun., 2007, 5188-5190.

[33] A. J. Perrotta, C. Kirby, B. R. Mitchell, E. R. Tucci, J. Catal., 1978, 55, 240-249.

[34] P. Massiani, F, Fajula, F. Figueras, J. Sanz, Zeolites, 1998, 8, 332-337.

[35] T. M. Lv, S. L. Zhang, Z. Feng, F.-S. Wang, S. Q. Zhang, J. Q. Zheng, X. Liu, C. G. Meng, Y. Wang, Cryst. Growth. Des., 2017, 17, 3940-3947.

[36] A. M. Gossens, E. J. P. Feijen, G. Verhoeven, B. H. Wouters, P. J. Gro-

[16] A. Martucci, A. Alberti, M. L. Guzman-Castillo, F. Di Renzo, F. Fajula, 
bet, P. A. Jacobs, J. A. Martens, Microporous Mesoporous Mater., 2000, 35, 555-572.

[37] A. Corma, Catal. Lett., 1993, 22, 33-52.

[38] P. Me'riaudeau, V. A. Tuan, V. T. Nghiem, S. Y. Lai, L. N. Hung, C. Naccache, J. Catal., 1997, 169, 55-66.

[39] H. Deldari, Appl. Catal. A, 2005, 293, 1-10.

[40] J. A. Martens, G. Vanbutsele, P. A. Jacobs, J. Denayer, R. Ocakoglu, G. Baron, J. A. Munoz, J. Thybaut, G. B. Marin, Catal. Today, 2001, 65, 111-116.

[41] E. Blomsma, J. A. Martens, P. A. Jacobs, J. Catal., 1997, 165, 241-248.

[42] W. G. Huang, D. D. Li, Y. H. Shi, X. H. Kang, X. B. Meng, K. Wang, W. Z. Dong, H. Nie, C. Li. Chin. J. Catal., 2003, 24, 651-657.

[43] J. B. Wang, J. Z. Li, S. T. Xu, Y. C. Zhi, Y. X. Wei, Y. L. He, J. R. Chen, M. Z. Zhang, Q. Y. Wang, W. N. Zhang, X. Q. Wu, X. W. Guo, Z. M. Liu. Chin. J. Catal., 2015, 36, 1392-1402.

[44] C. H. Geng, F. Zhang, Z. X. Gao, L. F. Zhou, J. L. Zhou, Catal. Today,
2004, 93, 485

[45] L. Guo, Y. Fan, X. Bao, G. Shi, H. Liu, J. Catal, 2013, 301, 162-173.

[46] P. Meriaudeau, V. A. Tuan, V. T. Nghiem, G. Sapaly, C. Naccache, J. Catal, 1999, 2, 435-444.

[47] X. Chen, X. J Meng, F.-S. Xiao. Chin. J. Catal., 2015, 36, 797-800.

[48] S. Y. Liu, J. Ren, H. K. Zhang, E. J. Lv, Y. Yang, Y. W. Li, J. Catal., 2016, $335,11-23$.

[49] G. Wang, Q. J. Liu, W. G. Su, X. J. Li, Z. X. Jiang, X. C. Fang, C. R. Han, C. Li, Appl. Catal. A, 2008, 335, 20-27.

[50] F. Zhang, Y. Liu, Q. Sun, Z. F. Dai, H. Gies, Q. M. Wu, S. X. Pan, C. Q. Bian, Z. J. Tian, X. J. Meng, Y. Zhang, X. D. Zou, X. F. Yi, A. M. Zheng, L. Wang, F.-S. Xiao, Chem. Commun., 2017, 53, 4942-4945.

[51] Y. Seo, S. Lee, C. Jo, R. Ryoo, J. Am. Chem. Soc., 2013, 135, 8806-8809.

[52] Y. Liu, W. Qu, W. W. Chang, S. X. Pan, Z. J. Tian, X. J. Meng, M. Rigutto, A. van der Made, L. Zhao, X. M. Zheng, F.-S. Xiao, J. Colloid Interface Sci., 2014, 418, 193-196.

\title{
高温快速合成纳米MAZ分子耖
}

\author{
章 芬章 凌, 杨志超 ${ }^{\mathrm{b}}$, 韩世超 ${ }^{\mathrm{a}}$, 朱秋艳 ${ }^{\mathrm{a}}$, 王 亮 ${ }^{\mathrm{a}}$, 刘晨光 ${ }^{\mathrm{b}}$, 孟祥举 ${ }^{\mathrm{a},{ }^{*}}$, 肖丰收, \#

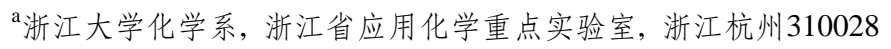 \\ ${ }^{\mathrm{b}}$ 中国石油大学(华东), 重油加工国家重点实验室, 催化重点实验室, 山东青岛 266580
}

\begin{abstract}
摘要: 作为重要的离子交换、吸附、分离与催化材料, 沸石分子篮广泛地应用于不同的工业过程中. MAZ (Omega)分子篮 的合成往往需要较长的晶化时间, 从而限制了它的广泛应用. 根据阿伦尼乌斯公式可以判断, 提高MAZ沸石分子筛的晶化 温度可以大幅度地缩短晶化时间, 达到快速合成沸石分子篮的目的. 本文将分子篮晶化温度从 100 提高到 $180{ }^{\circ} \mathrm{C}$, 在 $3.6 \mathrm{~h}$ 制 得MAZ沸石分子篎. X射线粉末衍射测试(XRD)表明, 所合成的样品是具有高纯度和高结晶度的MAZ沸石分子篮. 从扫描 电镜(SEM)图片可以看出, MAZ-180 (MAZ- $T, T$ 代表晶化温度)是由宽 $200 \mathrm{~nm}$ 、长2-3 $\mu \mathrm{m}$ 的纳米棒状组成. 为了探究这些纳 米棒状构成的形貌是否稳定, 将样品进行了超声处理. XRD和SEM结果表明, 经过处理的样品仍然具有原来的结晶度与形 貌, 确认了它们的结构稳定性. 高分辨透射图进一步确认了 MAZ-180样品的规整微孔结构. 热重分析显示该样品在 500-700 ${ }^{\circ} \mathrm{C}$ 出现两个放热峰, 这归因于有机模板的燃烧. 氮气吸附测试表明, MAZ-180的比表面积为 $187 \mathrm{~m}^{2} / \mathrm{g}$, 甚至超过低 温合成MAZ的表面积, 与它的高结晶度相一致.

将氢型MAZ-180 (H-MAZ-180)和MAZ-100 (H-MAZ-100)分子筛浸渍0.5\% Pt后, 用于正十二烷的加氢异构反应, 发现 Pt/H-MAZ-180催化剂总是具有更高的异构产物选择性和更低的裂化产物选择性. 这可能是因为MAZ-180样品具有更小的 尺寸, 更有利于反应中的扩散. MAZ-180沸石分子篎可快速合成的特点及其所表现出的优异的催化性能使其在未来广泛 应用于催化反应中成为可能.
\end{abstract}

关键词: 沸石分子筛MAZ; 快速晶化; 高温; 铂纳米粒子; 加氢异构反应

收稿日期: 2018-11-09. 接受日期: 2018-12-08. 出版日期: 2019-07-05.

*通讯联系人. 电话/传真: (0571)8273698; 电子信箱: mengxj@zju.edu.cn

\#通讯联系人. 电话/传真: (0571)8273698; 电子信箱: fsxiao@zju.edu.cn

基金来源: 国家自然科学基金(91545111, 91634201, 21720102001); 国家重点研究发展计划(2017YFB0702803); 壳牌基金.

本文的电子版全文由Elsevier出版社在ScienceDirect上出版(http://www.sciencedirect.com/science/journal/18722067). 